\title{
Effects of Mulching Soil on Water Consumption, Yield, Fruit Quality and Water Use Efficiency of "Canino" apricot (Prunus armeniaca L.) Cultivar El-Naggar, Y. I. ${ }^{1}$; T. A. Eid ${ }^{2}$ and S. A. M. Ali ${ }^{2}$ \\ ${ }^{1}$ Hort. Res. Inst., Agric. Res. Center, Giza, Egypt. \\ ${ }^{2}$ Soils, Water and Environ Res. Inst., Agric. Res. Center, Egypt.
}

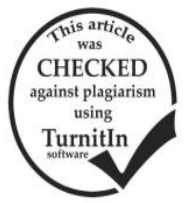

\section{ABSTRACT}

The present work was conducted at El-Kanater Horticultural Research Station on Canino apricot trees during 2016 and 2017 growing seasons to study the effect of different irrigation regimes (irrigation at both 25 and $50 \%$ of available soil moisture depletion) under mulching treatments; (black polyethylene plastic, white plastic and rice straw mulching) on evapotranspiration, water use efficiency, vegetative growth measurements, yield and fruit quality beside economic studies were also done. The most important results can be summarized as follows: Water consumption use (WCU) was increased in the case of frequent irrigation at $25 \%$ of available soil moisture depletion $\left(\mathrm{I}_{1}\right)$ value which was found to be 4137.4 and $3206.9 \mathrm{~m}^{3} / \mathrm{fed}$. in both growing seasons, respectively. Regarding mulching treatments, the values of the water consumption use were increased under both no mulching and rice straw mulching compared with either black plastic or white plastic mulching. Also, black plastic, white plastic and rice straw mulching generally led to increase (WUE) by $81.1 \%, 55.6 \%$ and $32.2 \%$ over the un-mulched treatment, respectively in both seasons and Kc values as compared to unmulched treatments. Moreover, all investigated fruiting parameters (fruit set \%, tree yield either as $\mathrm{kg}$ or as No. of fruits per tree, ton/fed and yield increment $\%$ as compared to the control) were significantly increased as a result of using mulching treatments in comparison with the control. It is quite clear that, leaf N, P and $\mathrm{K}$ contents were increased by using both black polyethylene plastic and white plastic mulching treatments in most cases as compared with control. Concerning the economic study, data indicated that, all mulching treatments were resulted in the higher values of profit per feddan as compared to the control treatment. Moreover the pest effective treatment in this respect was mulching with black plastic during both seasons of study. In general, it could be concluded that, both mulching treatments either with black polyethylene plastic or white plastic were most effective.

\section{INTRODUCTION}

Apricot is one of the few temperate fruit trees not affected by overproduction. Most apricot trees are cultivated in Mediterranean countries, where drought periods are increasingly common, a fact which makes irrigation water the most limiting factor for apricot productivity. Commercial apricot production depends on irrigation. For this reason, in this area the optimization of the use and efficiency of irrigation by means of deficit irrigation strategies that permit maximum yield whilst reducing water application is of a great importance.

Among the water management practices for increasing water use efficiency (WUE) is mulching. Any material spread on the soil surface to protect it from solar radiation or evaporation is called mulch. Different types of materials like wheat straw, rice straw, plastic film, grass, wood, sand etc. are used as mulches. They moderate soil temperature and increase water infiltration during intensive rain (Khurshid et al., 2006).

Surface irrigation method is most widely used all over the world (Mustafa et al., 2003). Irrigation is an important for all crops, because it influences on growth and development. Availability of adequate amount of moisture at critical stages of plant growth not only optimizes the metabolic process in plant cells, but also increase the effectiveness of the mineral nutrients applied to the crop. Consequently, any degree of water stress may produce deleterious effects on growth and yield of the crop (Saif et al., 2003).

Evaporation from the soil surface may account as much as $50 \%$ of the total moisture lost from the soil during the growing season for soybean and corn (Shaw, 1959). In this concern, mulching with plant residues and synthetic materials is a well-established technique for increasing the profitability of many horticultural crops (Gimenez et al., 2002).

Such effects are mainly contributed to the capacity of mulch to conserve soil moisture (Vavrina and Roka, 2000). In addition, soil temperature is very critical for biological and chemical processes that control nutrient cycling (Donk Van et al., 2004).

William and Lamont (1991) Black plastic is the most popular one because it retards weed growth and warms the soil in the spring. The results showed that the mulch made the harvest earlier in addition to reducing soil water loss.

Moreover, Douglas and Sanders (2001) and Sinkeviciene et al., (2009) stated that the advantages of using plastic mulches are: increasing soil temperature from 4 to 5 ${ }^{\circ} \mathrm{C}$ under black mulch, reducing soil compaction and both evaporation weed problems. Also, it is increasing growth and earlier crops.

Sharma et al., (2010) observed that mulching is very beneficial for enhancing moisture and nutrient conservation, resulting in increased productivity and improved soil conditions for cropping system.

The objective of this study are to investigate the effect of different available soil moisture depletion and was to investigate the effect of different mulching types on evapotranspiration, yield, fruit quality, water use efficiency, and net return of "Canino" apricot cultivar.

\section{MATERIALS AND METHODS}

The present investigation was undertaken during the two successive seasons of 2016 and 2017 at the Experimental Farm, El-Kanater Horticultural Research Station, Kalubeia Governorate Fruitful trees of "Canino" apricot (Prunus armeniaca L.) cultivar budded on apricot seedlings rootstock. The selected trees were about 18 years old grown on clay loamy soil and planted at $5 \times 5$ meters apart.

Soil samples from the experimental site were collected to determine main soil physical and chemical properties. Particle size distribution was conducted using the pipette method according to Klute (1986). Soil moisture constants were determined using the pressure membrane apparatus (Stackman 1966). The experimental soil was clay loamy in texture Table 1 and bulk density as well as watersoil characteristic is shown in Table 2. Meteorological data for the Agricultural Research Station are shown in Table 3. 
The experiment included eight treatments as follows:

Main plots (irrigation):

$\mathrm{I}_{1}$ : Irrigation when $25 \%$ of available soil moisture was depleted.

$\mathrm{I}_{2}$ : Irrigation when $50 \%$ of available soil moisture was depleted.

Sub-plots (mulching):

1- Black polyethylene plastic sheet (25micron) used to cover soil surface under the plants.

2- White plastic film mulch.

3- Rice straw mulch $30 \mathrm{~cm}$ thick was spread out on the soil surface to cover the soil completely.

4- No soil mulching (control).

All mulch treatments were applied on the $1^{\text {st }}$ week of March on the soil up to the end of the season.

Irrigation started after trees received the winter irrigation on March i.e., starting from bud swelling stage. Irrigation was done when moisture reached the relevant level to determine available soil water retained in the soil. Soil moisture was determined grave metrically on oven dry basis of soil samples taken to a depth of $15 \mathrm{~cm}$. up to $60 \mathrm{~cm}$..
Table 1. Physical properties of the experimental soil.

\begin{tabular}{lc}
\hline Parameter & Value \\
\hline Particle size distribution (\%): & 32.2 \\
Clay \% & 34.5 \\
Silt \% & 32.2 \\
Fine sand \% & 1.1 \\
Coarse sand \% & Clay loamy \\
Texture class &
\end{tabular}

Table 2. Some soil - water properties and bulk density

\begin{tabular}{|c|c|c|c|c|c|c|c|}
\hline \multirow{2}{*}{ Depth } & \multicolumn{2}{|c|}{$\begin{array}{c}\text { Field capacity } \\
\text { (FC) }\end{array}$} & \multicolumn{2}{|c|}{$\begin{array}{c}\text { Wilting } \\
\text { Point (WP) }\end{array}$} & \multicolumn{2}{|c|}{$\begin{array}{c}\text { Available } \\
\text { water (AW) }\end{array}$} & \multirow{2}{*}{$\begin{array}{c}\text { Bulk } \\
\text { density } \\
\text { (BD) } \\
\text { g/cm }\end{array}$} \\
\hline & $\begin{array}{c}\% \text { by } \\
\text { weight }\end{array}$ & n & $\begin{array}{c}\% \text { by } \\
\text { weight }\end{array}$ & cm & $\begin{array}{c}\% \text { by } \\
\text { weight }\end{array}$ & $\mathrm{Cm}$ & \\
\hline 15 & 38.5 & 7.22 & 18 & 3.3 & 20 & 3. & 1.25 \\
\hline 5-30 & 37 & 7. & 17.4 & 3.3 & 19 & 3. & 1. \\
\hline $30-45$ & 34. & 6.77 & 16.3 & 3.2 & 17 & 3.5 & 1. \\
\hline $45-60$ & 33.4 & 6.81 & 16.1 & 3.28 & 17.3 & 3.53 & 1.36 \\
\hline Total & & 27.98 & & 13.92 & & 14.06 & \\
\hline
\end{tabular}

FC: moisture at $33 \mathrm{KPa}(0.33$ bar) moisture tension.

WP: moisture at $1.5 \mathrm{MPa}(15 \mathrm{bar})$ moisture tension.

AW $=$ FC-WP

Table 3. Meteorological data in 2016 and 2017 seasons.

\begin{tabular}{|c|c|c|c|c|c|c|c|c|c|c|c|c|}
\hline \multirow{2}{*}{$\begin{array}{l}\text { Season } \\
\text { Month }\end{array}$} & \multicolumn{6}{|c|}{2016} & \multicolumn{6}{|c|}{2017} \\
\hline & T. max & T. min & W.S & R.H & S.S & R.F & T. max & T. min & W.S & R.H & S.S & R.F \\
\hline Feb. & 23.70 & 9.10 & 3.60 & 51.00 & 8.20 & 19.40 & 20.40 & 9.20 & 3.20 & 62.60 & 8.20 & 5.10 \\
\hline Mar. & 26.40 & 11.30 & 4.10 & 43.00 & 8.60 & 1.50 & 24.80 & 10.40 & 3.60 & 51.30 & 8.60 & 4.20 \\
\hline Apr. & 32.80 & 14.20 & 4.20 & 37.00 & 9.60 & 5.60 & 28.90 & 12.40 & 3.90 & 45.40 & 9.60 & 28.20 \\
\hline May & 34.30 & 17.30 & 4.40 & 35.00 & 10.80 & 1.30 & 34.50 & 17.40 & 3.10 & 37.10 & 10.80 & 9.60 \\
\hline Jun. & 39.40 & 21.20 & 4.20 & 32.00 & 12.00 & 0.00 & 38.00 & 20.30 & 3.20 & 36.20 & 12.00 & 1.90 \\
\hline Jul. & 39.90 & 17.90 & 3.90 & 35.00 & 11.70 & 0.00 & 40.10 & 22.80 & 3.00 & 37.60 & 11.70 & 0.00 \\
\hline Aug. & 37.80 & 21.90 & 4.10 & 44.00 & 11.10 & 0.00 & 38.60 & 22.80 & 2.80 & 42.60 & 11.10 & 0.00 \\
\hline Sep. & 35.40 & 20.20 & 3.90 & 47.00 & 10.30 & 0.00 & 36.20 & 19.80 & 2.80 & 45.90 & 10.30 & 0.00 \\
\hline Oct. & 32.00 & 17.80 & 3.80 & 55.00 & 9.20 & 2.20 & 30.40 & 16.70 & 2.60 & 52.20 & 9.20 & 14.40 \\
\hline
\end{tabular}

Where: T. max., T. min.= maximum and minimum temperatures ${ }^{\circ} \mathrm{C} ; \mathrm{W} . S=$ wind speed $(\mathrm{m} / \mathrm{sec}) ;$ R.H. $=$ relative humidity $(\%) ;$ S.S $=$ actual sun shine (hour); $\mathrm{S} . \mathrm{R}=$ solar radiation $\left(\mathrm{cal} / \mathrm{cm}^{2} /\right.$ day). $\mathrm{RF}=$ rainfall $(\mathrm{mm} / \mathrm{month})$.[Data were obtained from the agro meteorological Unit at SWERI, ARC]

Water consumption use (WCU):

Water consumption use or actual evapotranspiration (ETc) values were calculated for each irrigation treatment using the following formula (Israelson and Hansen, 1962).

Where:

$$
\text { WCU }=\sum_{i=1}^{i=4} \frac{\left(\theta_{2}-\theta_{1}\right)}{100} \times B d \times D
$$

WCU $=$ seasonal water consumption use $(\mathrm{cm})$.

$\Theta_{2}=$ soil moisture content after irrigation (on mass basis, $\%$ ).

$\Theta_{1}=$ soil moisture content before irrigation (on mass basis, \%).

$\mathrm{Bd}=$ soil bulk density $\left(\mathrm{g} / \mathrm{cm}^{3}\right)$.

$D=$ depth of soil layer $(15 \mathrm{~cm}$ each $)$.

$\mathrm{i}=$ number of soil layer.

Soil moisture content was gravimetrically determined in soil samples taken from consecutive depths from $15 \mathrm{~cm}$ down to $60 \mathrm{~cm}$. Soil samples were collected just before each irrigation 48 hours after irrigation and at harvest time

Calculation of crop coefficient and evapotranspiration: Reference evapotranspiration (ETo):

Reference evapotranspiration (ETo) was calculated using the meteorological data as cited by Doorenbos and Pruitt, (1977) and Allen et al., (1998) as follows: -

The Penman-Monteith equation for estimating potential evapotranspiration Penman Monteith was applied by using CROP WAT model (Smith 1991).

Water use efficiency (W.U.E.):

The production of apricot fruits by one cubic meter of irrigation water (fruit yield in $\mathrm{kg} /$ feddan $/ \mathrm{m}^{3}$ water consumed/feddan), as affected by different treatments was calculated by the following equation (Vites, 1965):

\section{W.U.E $=$}

Fruits yield (kg)/feddan

Seasonal ET $\left(\mathrm{m}^{3} /\right.$ water consumed $) /$ feddan

* Vegetative growth measurements

An influence of different treatments in this study on some vegetative growth parameters were evaluated through determining the average shoot length $(\mathrm{cm})$, number of leaves/ shoot and leaf area $\left(\mathrm{cm}^{2}\right)$ using portable leaf area meter [Moedl: YMI-A20110122-1]. Therefore, four main branches in different direction of each replicate were labeled On each selected branch ten newly emerging shoots were tagged. On August all current shoots developed on those branches were used for measuring the abovementioned vegetative growth parameters.

* Fruiting and yield parameters:

\section{A- Fruiting parameters.}

- Fruit set percentage.

In both seasons the initial numbers of flowers at full bloom stage were recorded per each tree in all treatments then, fruit set percentage was estimated according to the following equation

$$
\text { Fruit set }(\%)=\frac{\text { Number of developed fruitlets }}{\text { Total number of flowers at full bloom }} \times 100
$$


B- Yield parameters (Kg/tree, No of fruits/tree and ton/feddan):

At harvest time, yield of each tree was separately picked up then counted and weighed in Kgs. Therefore, the yield as $\mathrm{Kg}$ / tree, number of fruits per tree and ton/feddan were estimated.

* Fruit quality:

Ten fruits were randomly sampled from each individual tree (replicate) for determining some physical and chemical properties of fruits.

\section{A- Fruit physical properties:}

Both the average values of fruit weight (gm) and fruit firmness $\left(\mathrm{Ib} / \mathrm{inch}^{2}\right.$ ) was determined using Magness and Taylor (1980) pressure tester with $7 / 18$ inch plinger were the two physical studied characters.

\section{B-Fruit chemical properties:}

Fruit juice TSS (\%) was determined by using a Carl-Zeiss hand refractometer according to A.O.A.C (2000) and fruit juice total acidity percentage was measured according to Vogel (1968) as well as TSS/acid ratio was estimated by divided TSS (\%) over total acidity (\%). Furthermore, fruit juice total sugar was calculated calorimetrically according to the method described by Malik and Singh (1980).

\section{* Leaf nutrient composition:}

On mid-August in the two seasons of study, leaf samples of twenty mature leaves were wiped with distilled water then, oven dried at $70{ }^{\circ} \mathrm{C}$.till constant weight ground and stored in smell begs for the determination of $\mathrm{N}, \mathrm{P}$ and $\mathrm{K}$ using the following procedures.

Total nitrogen: total nitrogen content was determined by the modified micro Kjeldehl method according to Cottenie et al., (1982).

Total phosphorus: determination was carried out colorimeterically according to Murphy and Riely (1962).

Total potassium: total $\mathrm{K}$ content was determined using the atomic absorption spectrophotomer (3300) according to Jackson and Ulrich (1959).

* Statistical analysis

All obtained data during both seasons were statistically analyzed using the analysis of variance method according to Snedecor and Cochran (1990). However means distinguished by method described by Weller and Duncan (1969).

\section{RESULTS AND DISCUSSION}

\section{Soil-water relations:}

Water consumptive use:

Water consumptive use is the combination of two processes; evaporation and transpiration. Evaporation is the direct vaporization of water from the soil surface and from plant surfaces. Transpiration is the flow of water vapor from the interior of the plant to the atmosphere (Jones et al., 1984).

The seasonal changes in the actual evapotranspiration ETa for apricot trees was affected by different mulching treatments during the growing seasons the data of both seasons illustrated in Fig. (1). The main effect of irrigation treatments shows that $I_{1}$ gave the highest water consumption use WCU followed by $\mathrm{I}_{2}$. Mean values were 4137.4 and $3206.9 \mathrm{~m}^{3} / \mathrm{fed}$. in the first season and 4052.7 and 3135.9 $\mathrm{m} 3 /$ fed. in the second one for $I_{1}$ and $I_{2}$, respectively. Such result might be reasonable, since more frequent irrigation period provide high evaporation opportunity from the relatively wet rather than dry soil surface (Levitt et al., 1995 and Devit et al., 1994).

The Water consumptive use (i.e. WCU or ETa.) values under soil mulching are lower than the WCU values under un-mulching soil. Black polyethylene plastic mulch treatment recorded the lowest values of WCU followed by white plastic then rice straw mulch treatments as compared to the un-mulched treatments. As it registered 4344.8, $3550.3,3362.2$ and $3120.0 \mathrm{~m}^{3} / \mathrm{fed}$. in the first season and $4427.5,3595.6,3439.1$ and $3226.5 \mathrm{~m}^{3} / \mathrm{fed}$. in the second one for un-mulched, rice straw, white plastic and black polyethylene plastic mulch treatments, respectively.

These results may be due to the role of mulches in reducing evaporation and keeping soil moisture at root zone to a longer period. In addition, both soil mulching treatments significantly reduced total consumptive use $\mathrm{m} 3 / \mathrm{fed}$, as compared to bare soil in the two seasons of study as shown in Table 3. These results are supported by the observation of Khalifa (1994), El-Henawy (2006) and Mikhael (2007). They mentioned that, monthly and seasonal water consumptive uses of citrus were decreased as affected by different type of mulching.

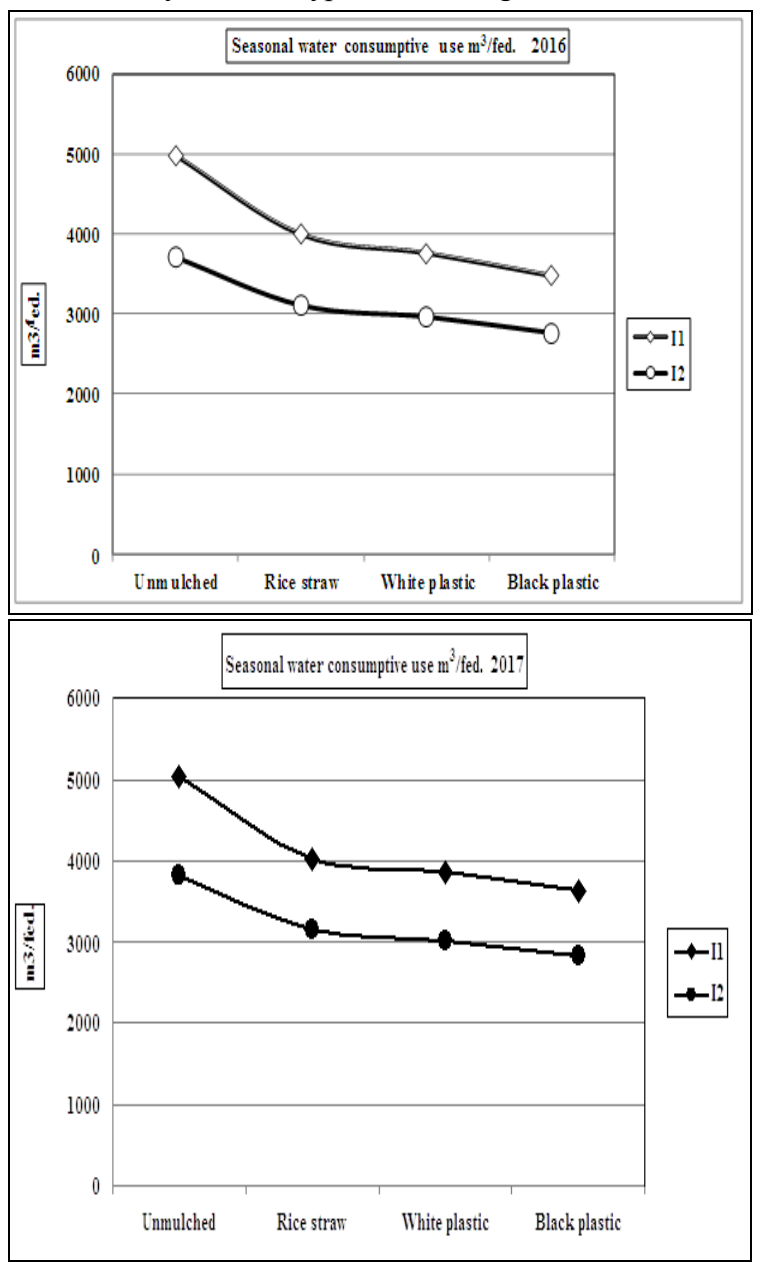

Fig. 1. Seasonal water consumptive use $\left(\mathrm{m}^{3} /\right.$ fed.) for apricot trees as affected by soil moisture regimes and different mulching treatments. 
Monthly water consumptive use:

Monthly water consumption started low when tree leaves were small and increased gradually with increased tree growth reaching a maximum in July, mainly due to increased demand for water by trees.

Regarding the effect of irrigation and mulching treatments and their interaction on monthly and total water consumptive use $\mathrm{CU}$ for apricot trees, the data of both seasons illustrated in Fig. 2 showed that, monthly values of water consumptive use, $\mathrm{mm}$ were gradually increased starting from February and reached the maximum values during July, then declined from October. These could be attributed to luxuriant growth of apricot trees in this period. This trend was found to be true under all mulching treatments. The data also show that, monthly values of water consumptive used of apricot trees under soil mulching with black plastic, White plastic and rice straw were the lowest. Meanwhile, the highest values were observed under unmulched one (bare soil). Weagand (1962) pointed out that, the drying rate of bare soil is positively related to the water content and relatively related to lime, and that a drying front advances into the soil linearly. Ibrahim (1981) concluded that the increase in evapotranspiration by maintaining soil moisture at a high level is attributed to excess available water in the root zone.
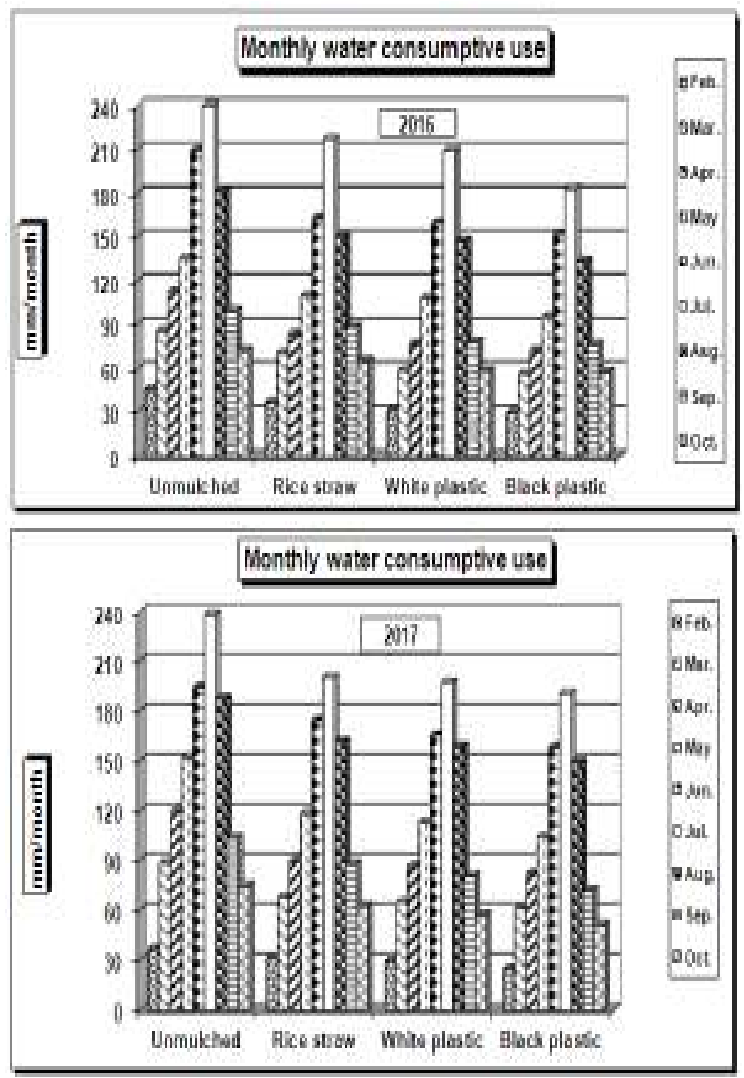

Fig. 2. Monthly water consumptive use $\mathrm{mm} / \mathrm{month}$ for apricot trees as affected by different mulching treatments during 2016 and 2017 seasons.

Reference evapotranspiration (ETo):

The major parameters required to calculate the ETo are the climatological data, length of growth period of the cultivated crops and surface properties. Data illustrated in Table (4) show that, the values of reference evapotranspiration (ETo) which were calculated according to Penman-Monteith equation reached the maximum in June and July while February and October reflected the minimum value in both 2016 and 2017 seasons. This trend is due to the variation in climate during the two seasons of study.

Table 4. Monthly ETa and ETo $\mathrm{mm} / \mathrm{month}$ for apricot trees as affected by the different treatments according to the studied equation during 2016 and 2017 seasons.

\begin{tabular}{|c|c|c|c|c|c|}
\hline \multicolumn{5}{|c|}{$\begin{array}{c}\text { ETa } \mathrm{mm} / \text { month Actual water } \\
\text { consumption use }\end{array}$} & $\begin{array}{c}\text { ETo mm/ } \\
\text { month }\end{array}$ \\
\hline \multicolumn{6}{|c|}{ First season 2016} \\
\hline Months & $\begin{array}{l}\text { Black } \\
\text { plastic }\end{array}$ & $\begin{array}{l}\text { White } \\
\text { plastic }\end{array}$ & $\begin{array}{c}\text { Rice } \\
\text { straw }\end{array}$ & Unmulched & $\begin{array}{l}\text { Penman- } \\
\text { Monteith }\end{array}$ \\
\hline February & 30 & 27.5 & 33.5 & 45.9 & 89.3 \\
\hline March & 52.5 & 55.1 & 66.5 & 85.7 & 140.4 \\
\hline April & 68.3 & 73.4 & 79.6 & 112.8 & 183.0 \\
\hline May & 91.6 & 104.32 & 105.6 & 135.26 & 227.2 \\
\hline June & 158.6 & 166.5 & 169.2 & 219.3 & 265.5 \\
\hline July & 169.5 & 195.2 & 203.8 & 232.3 & 261.0 \\
\hline August & 130 & 143.5 & 146.2 & 181.9 & 209.9 \\
\hline September & 73 & 74.7 & 84.9 & 100.2 & 169.5 \\
\hline October & 54.2 & 55.1 & 61.6 & 72.5 & 135.8 \\
\hline Seasonal mm & 827.7 & 895.32 & 950.87 & 1185.86 & 1681.7 \\
\hline \multicolumn{6}{|c|}{ Second season 2017} \\
\hline February & 25.0 & 25.5 & 27.5 & 37 & 9.3 \\
\hline March & 57.4 & 60.9 & 64.2 & 88.6 & 151.0 \\
\hline April & 78.2 & 82.7 & 85.9 & 120 & 195.0 \\
\hline May & 100.5 & 109.3 & 114.5 & 152.3 & 240.9 \\
\hline June & 159.3 & 166.5 & 175.5 & 199.4 & 267.3 \\
\hline July & 176.9 & 183.4 & 186.5 & 228.4 & 278.1 \\
\hline August & 150.4 & 160 & 163 & 192.8 & 249.6 \\
\hline September & 68.5 & 77.2 & 84.4 & 104 & 207.9 \\
\hline October & 47.4 & 53.4 & 58.7 & 74.9 & 152.2 \\
\hline Seasonal mm & 863.9 & 918.9 & 960.2 & 1197.4 & 1831.2 \\
\hline
\end{tabular}

\section{Crop coefficient (Kc):}

The equations were used to assess the extent of closeness of each estimate with the actual values obtained by direct measurement with $\left(\mathrm{I}_{1}\right)$ irrigation when $25 \%$ of available soil moisture was depleted. The equation is the Penman-Monteith was applied by using CROP WAT model. The actual crop coefficient $(\mathrm{Kc})$ was calculated for the different types of mulching are shown in Table (5). The maximum un-mulching values $(0.93$ and 0.86$)$ were obtained in July, while the minimum values (0.51 and 0.41$)$ were obtained in February in both seasons, respectively. The actual $(\mathrm{Kc})$ increased from February to July, then declined in September and October in both seasons. The actual minimum $(\mathrm{Kc})$ values were obtained under black plastic mulch, followed by white plastic then rice straw mulch treatment, while unmulched came in the fourth the rank in this respect. Most crops do not require much water during the season as would be needed to meet the potential evapotranspiration, even though adequate soil moisture can be provided (Jensen, 1968). Thus, the term crop coefficient is used to differentiate water requirements of crops. For the determination of crop coefficient, both actual and potential evapotranspiration are measured concurrently.

\section{Water use efficiency (WUE):}

WUE is defined as the ratio of yield to water consumptive use, when applied and stored water does not evaporate, but is used by the crop to produce additional fruit yield as a function of multiple factors, including physiological characteristics of apricot trees, and soil characteristics, meteorological conditions and agronomic practices. Water 
use efficiencies (WUE) calculated for the different studied treatments are shown in Fig. 3. In general, the values of water use efficiency (WUE) increased with the applying of mulch treatments. The highest increase in (WUE) was obtained under black plastic mulch followed by white plastic then rice straw mulches as compared to un-mulched treatment in both seasons. Average values of (WUE) were ( $5.05 \& 5.07$ ), (4.13 $\& 4.56),(3.63 \& 3.76)$ and $(2.73 \& 2.86) \mathrm{kg}$ fruit $/ \mathrm{m}^{3}$ water for black plastic, white plastic, rice straw mulching and unmulching in both seasons, respectively. This may be due to yield increment under mulching treatments as a result of increasing water availability and decreasing both the weed and water evapotranspiration. Black plastic, white plastic and rice straw mulching generally led to increase (WUE) by 81.1 $\%, 55.6 \%$ and 32.2. \% over the un-mulched treatment, respectively in both seasons. Significant differences in (WUE) among treatments were obtained. These results are in agreement with those obtained by El-Henawy (2006) who reported that, WUE values under soil mulching were higher than under bare soil.

Table 5. Calculated and theoretical crop coefficient $(\mathrm{Kc})$ for apricot trees under mulched and un-mulched conditions during 2016 and 2017 seasons.

\begin{tabular}{lcccccccc}
\hline & \multicolumn{3}{c}{ First season (2016) } & \multicolumn{5}{c}{ Second season (2017) } \\
\hline Months & Unmulched & Rice straw & White plastic & Black plastic & Unmulched & Rice straw & White plastic & Black plastic \\
\hline February & 0.51 & 0.38 & 0.31 & 0.34 & 0.41 & 0.31 & 0.29 & 0.28 \\
March & 0.61 & 0.47 & 0.39 & 0.37 & 0.59 & 0.43 & 0.4 & 0.38 \\
April & 0.62 & 0.43 & 0.4 & 0.37 & 0.62 & 0.44 & 0.42 & 0.4 \\
May & 0.6 & 0.46 & 0.46 & 0.4 & 0.63 & 0.48 & 0.45 & 0.42 \\
June & 0.79 & 0.6 & 0.59 & 0.56 & 0.73 & 0.64 & 0.6 & 0.58 \\
July & 0.93 & 0.82 & 0.79 & 0.69 & 0.86 & 0.71 & 0.7 & 0.67 \\
August & 0.87 & 0.7 & 0.68 & 0.62 & 0.75 & 0.63 & 0.62 & 0.58 \\
September & 0.59 & 0.5 & 0.44 & 0.43 & 0.5 & 0.41 & 0.37 & 0.33 \\
October & 0.53 & 0.45 & 0.41 & 0.4 & 0.49 & 0.39 & 0.35 & 0.31
\end{tabular}

\section{Some vegetative growth measurements:}

Data represented in Table (6) showed the effects of mulching, water irrigation regime and their interaction on some vegetative growth parameters i.e; shoot length $(\mathrm{cm})$, number of leaves per shoot and leaf area $\left(\mathrm{cm}^{2}\right)$. Obteined results disclosed clearly that an obvious significantly increased in three grwoth parameters was generaly exhibited with all mulching treatments as compared to the control in the two seasons of study. However, the mulching with black plastic treatment gave the highest significant values in shoot length, number of leaves/shoot and leaf area of apricot trees. $(51.8 \& 52.1 \mathrm{~cm}),(35.1 \& 35.4)$ and (53.9 \& 54.4) in both 2016 and 2017 seasons, respectively. In the same context the other two mulching treatments (white plastic and rice straw) was significantly in between the abovementioned two extremes in the two seasons of study. Moreover, as the differences between the two levels of irrigation regime were significant whereas, the longest shoot length the highest number of leaves/shoot and the greatest values of leaf area were obtained when appling 25 $\%\left(\mathrm{I}_{1}\right)$ of available soil mositure wsa deplated as compared to the level of $50 \%\left(\mathrm{I}_{2}\right)$ of avaliable soil mositure was depleted treatment duringboth first and second seasons of study. On the other hand, regarding the interaction effect between deffrent mulching $\mathrm{x}$ irrigation regyme treatments under study, obtained results showed obviously that, (mulching with black plastic $\mathrm{x}$ level $\mathrm{I}_{1}, 25 \%$ ) combination treatment was statistically the superior as had the longest shoots with the highest values for both number of leaves/ shoot and leaf area as compared to the other investigated combination treatments. Meanwhile, the least values of tested grwoth the parameters was always in concomitant to control which was significantly the infirior. In addition, the other combination treatments were statistically intermediate the two extents. Such trend was true during both 2016 and 2017 seasons. Similar observations were also attained by Liu et al. (2014) who reported that, the benefits of using mulch in orchards have been reported in many parts of the world to protect plants from extreme transpiration fluctuation and regulation of soil temperature. Moreover, using mulches help in moisture conservation and reduction of evaporation (Sinkeviciene et al. 2009), increased soil organic matter (Kiristina et al. 2013), and it is considered as a source of plant nutrients (Hostetler et al. 2007).
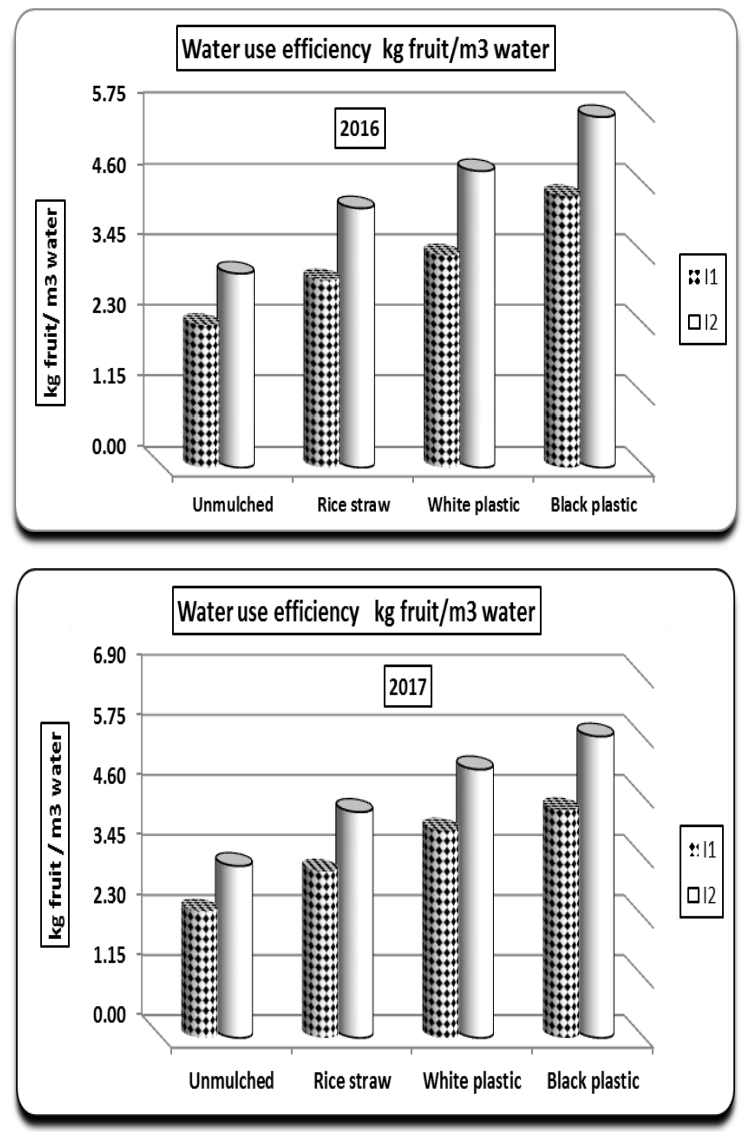

Figure 3. Effect of soil moisture regimes and mulching treatments on water use efficiency (WUE) $\mathrm{Kg} / \mathrm{m}^{3}$ for apricot trees. 
Table 6. Effect of water irrigation regime, mulching treatments and their interaction on some vegetative growth of apricot trees during 2016 and 2017 seasons.

\begin{tabular}{|c|c|c|c|c|c|c|c|c|c|}
\hline \multirow{2}{*}{$\begin{array}{l}\text { Irrigation } \\
\text { Mulching }\end{array}$} & \multicolumn{3}{|c|}{ Shoot length cm } & \multicolumn{3}{|c|}{ No. of leaves/shoot } & \multicolumn{3}{|c|}{ Leaf area $\left(\mathrm{cm}^{2}\right)$} \\
\hline & $\mathbf{I}_{1}$ & $\mathbf{I}_{2}$ & Mean & $\mathbf{I}_{1}$ & $\mathbf{I}_{2}$ & Mean & $\mathbf{I}_{1}$ & $\mathbf{I}_{2}$ & Mean \\
\hline & \multicolumn{9}{|c|}{ First season; 2016} \\
\hline Control & $45.47 f$ & $42.7 \mathrm{~g}$ & $44.1 \mathrm{D}$ & $26.9 \mathrm{e}$ & $25.4 \mathrm{f}$ & $26.2 \mathrm{D}$ & $40.8 \mathrm{ef}$ & $39.4 \mathrm{f}$ & $40.1 \mathrm{D}$ \\
\hline Rice straw & $47.97 d$ & $45.6 \mathrm{f}$ & $46.8 \mathrm{C}$ & $30.3 \mathrm{c}$ & $28.3 d$ & $29.3 \mathrm{C}$ & $44.2 \mathrm{~d}$ & $41.8 \mathrm{e}$ & $42.9 \mathrm{C}$ \\
\hline White plastic & $49.70 \mathrm{c}$ & $47.0 \mathrm{e}$ & $48.4 \mathrm{~B}$ & $33.4 b$ & $30.7 \mathrm{c}$ & $32.1 \mathrm{~B}$ & $49.8 b$ & $47.9 \mathrm{c}$ & 48.9B \\
\hline Black plastic & $52.37 \mathrm{a}$ & $51.2 \mathrm{~b}$ & $51.8 \mathrm{~A}$ & $35.0 \mathrm{a}$ & $35.2 \mathrm{a}$ & $35.1 \mathrm{~A}$ & $54.6 \mathrm{a}$ & $53.3 \mathrm{a}$ & $53.9 \mathrm{~A}$ \\
\hline \multirow[t]{2}{*}{ Mean } & $48.9 \mathrm{~A}$ & $46.6 \mathrm{~B}$ & & $31.4 \mathrm{~A}$ & 29.9B & & $47.4 \mathrm{~A}$ & $45.6 \mathrm{~B}$ & \\
\hline & \multicolumn{9}{|c|}{ Second season; 2017} \\
\hline Control & $46.3 \mathrm{f}$ & $44.7 \mathrm{~g}$ & $45.5 \mathrm{D}$ & $28.6 \mathrm{e}$ & $26.4 \mathrm{f}$ & $27.5 \mathrm{D}$ & $43.3 \mathrm{e}$ & $41.5 \mathrm{f}$ & $42.4 \mathrm{D}$ \\
\hline Rice straw & $49.0 \mathrm{~d}$ & $47.4 \mathrm{e}$ & $48.2 \mathrm{C}$ & $29.4 \mathrm{c}$ & $27.6 \mathrm{~d}$ & $28.6 \mathrm{C}$ & $47.8 \mathrm{~cd}$ & $46.2 \mathrm{~d}$ & $47.0 \mathrm{C}$ \\
\hline White plastic & $50.3 \mathrm{c}$ & $48.3 b$ & 49.3B & $32.8 b$ & $31.8 \mathrm{bc}$ & $32.3 \mathrm{~B}$ & $50.6 b$ & $49.2 \mathrm{bc}$ & 49.9B \\
\hline Black plastic & $52.9 \mathrm{a}$ & $51.3 b$ & $52.1 \mathrm{~A}$ & $35.4 \mathrm{a}$ & $35.4 \mathrm{a}$ & $35.4 \mathrm{~A}$ & $55.1 \mathrm{a}$ & $53.6 \mathrm{a}$ & $54.4 \mathrm{~A}$ \\
\hline Mean & $49.6 \mathrm{~A}$ & $47.9 \mathrm{~B}$ & & $31.6 \mathrm{~A}$ & $30.3 \mathrm{~B}$ & & $49.2 \mathrm{~A}$ & $47.6 \mathrm{~B}$ & \\
\hline
\end{tabular}

Means followed with the same letter (s) within each column or row are not significantly different according to Duncan's Multiple Range test at $5 \%$ level. $I_{1}$ : irrigation when $25 \%$ of available soil moisture was depleted.

$\mathbf{I}_{2}$ : Irrigation when $50 \%$ of available soil moisture was depleted.

2) Some fruiting parameters:

With respect to the effect of some mulching treatments during both $1^{\text {st }}$ and $2^{\text {nd }}$ seasons of study obtained data tabulated in Table (7) displayed clearly that,trees were treated with black plastic, white plastic \& rice straw had significantlly the highest values of all fruiting parameters: i.e., fruit set $\%$, yeild as either $\mathrm{Kg} /$ tree or ton/fed and number of fruits as compared to the control while, the least significant values of abovmentioned investigated fruiting parameters were statistically exhibited by those untreated apricot trees (control). Moreover, trees treated with black plastic gave the highest significant values in all studied fruting parameters while both mulching tretments (white plastic and rice straw) were in between as compared to the aforesaid two extents. Such trend was detected during both seasons of study.

As for the effect of the two levels of irrigation regames $\left(\mathrm{I}_{1}\right.$ and $\left.\mathrm{I}_{2}\right)$ on some fruiting parameters, data in the same Table indicated that,apricot trees irrigated with the first level $\left(\mathrm{I}_{1}\right)$ i.e., $(25 \%)$ was sgnificantly superior treatment to improving and icreasing all studied fruiting parametrs (fruit set $\%$, yield $\mathrm{kg} /$ tree, yield ton/fed. and yield as No. of fruits) as compared to the second level $\left(\mathrm{I}_{2}, 50 \%\right)$ which had the least valus of abovementioned fruiting parameters during the first and second seasons of study
Regarding the interaction effect of different combination treatments, data revealed that the effect of any studied factor in this investigation was dirctedy reflected on the interaction effect of its own combinatin. Wheres, trees traeted with (black plastic $\mathrm{x} \mathrm{I}_{1}$ ) combination treatment was the most effective treatment which resulted statistically in the highest values of fruit set $\%$ and the heaviest yield either as $\mathrm{Kg} /$ tree or ton/fed. and no.of fruits. However, the least values of fruiting parameters were always inconcomitant to that apricot trees tearated with the control. On the other hand, the other combinations treatments was intermediate as compared to the aforesaid two extremes. Such trend was true in the two seasons of study.

Similar observations were also attained by Sajjapongese et al., (1989) revealed that yield increased by $67.5 \%$ when the crop mulched with black plastic and by $15 \%$ when rice straw used as mulch. Sharma et al., (2010) observed that, mulching is very beneficial for enhancing moisture and nutrient conservation, resulting in increased productivity and improved soil conditions for cropping system. William and Lamont (1991) black plastic are the most popular one because it retards weed growth and warms the soil in the spring. The results showed that the mulch made the harvest earlier in addition to reducing soil water loss.

Table 7. Effect of water irrigation regime, mulching treatments and their interaction on fruiting and yield parameters of apricot trees during 2016 and 2017 seasons.

\begin{tabular}{|c|c|c|c|c|c|c|c|c|c|c|c|c|}
\hline \multirow{3}{*}{$\begin{array}{l}\text { Irrigation } \\
\text { Mulching }\end{array}$} & \multirow{2}{*}{\multicolumn{3}{|c|}{$\begin{array}{c}\text { Fruiting parameters } \\
\text { Fruit set } \%\end{array}$}} & \multicolumn{9}{|c|}{ Yield parameters } \\
\hline & & & & \multicolumn{3}{|c|}{ No. of fruits/tree } & \multicolumn{3}{|c|}{ (Kg / tree) } & \multicolumn{3}{|c|}{ (Ton/fed.) } \\
\hline & $\mathbf{I}_{1}$ & $\mathbf{I}_{2}$ & Mean & $I_{1}$ & $\mathbf{I}_{2}$ & Mean & $\mathbf{I}_{1}$ & $\mathbf{I}_{2}$ & Mean & $I_{1}$ & $\mathbf{I}_{2}$ & Mean \\
\hline & \multicolumn{12}{|c|}{ Season; 2016} \\
\hline Control & $8.48 \mathrm{~d}$ & $8.07 \mathrm{~d}$ & $8.28 \mathrm{D}$ & $2040 f$ & $2022 \mathrm{~g}$ & 2031D & $1.79 \mathrm{f}$ & $68.46 \mathrm{~g}$ & $70.13 \mathrm{D}$ & $13.13 \mathrm{~d}$ & $11.50 \mathrm{~d}$ & $12.31 \mathrm{C}$ \\
\hline Rice straw & $9.27 \mathrm{c}$ & $8.61 d$ & $8.94 \mathrm{C}$ & $2115 d$ & $1986 \mathrm{~h}$ & $2051 \mathrm{C}$ & $81.05 \mathrm{~d}$ & $75.07 \mathrm{e}$ & $78.06 \mathrm{C}$ & $13.32 \mathrm{~cd}$ & $11.97 \mathrm{bd}$ & $12.65 \mathrm{BC}$ \\
\hline White plastic & $10.23 b$ & $9.25 \mathrm{c}$ & $9.74 \mathrm{~B}$ & $2275 c$ & $2070 \mathrm{e}$ & 2173B & $88.63 \mathrm{c}$ & $80.23 d$ & $84.43 \mathrm{~B}$ & $13.48 \mathrm{ad}$ & $12.32 \mathrm{ac}$ & $12.90 \mathrm{AB}$ \\
\hline Black plastic & $11.69 \mathrm{a}$ & $9.82 \mathrm{bc}$ & $10.75 \mathrm{~A}$ & $2403 a$ & $2340 \mathrm{~b}$ & $2372 \mathrm{~A}$ & $97.72 \mathrm{a}$ & $94.90 \mathrm{~b}$ & $96.31 \mathrm{~A}$ & $13.65 \mathrm{ab}$ & $12.61 \mathrm{a}$ & $13.13 \mathrm{~A}$ \\
\hline \multirow[t]{2}{*}{ Mean } & $9.92 \mathrm{~A}$ & 8.94B & & $2208 \mathrm{~A}$ & 2105B & & $84.80 \mathrm{~A}$ & 79.67B & & $13.40 \mathrm{~A}$ & $12.10 \mathrm{~A}$ & \\
\hline & \multicolumn{12}{|c|}{ Season; 2017} \\
\hline Control & $9.80 \mathrm{c}$ & $8.46 \mathrm{e}$ & $9.13 \mathrm{C}$ & $2103 f$ & $1995 \mathrm{~h}$ & 2049D & $77.83 \mathrm{e}$ & $72.57 f$ & $75.20 \mathrm{D}$ & $14.49 \mathrm{c}$ & $12.25 \mathrm{c}$ & $13.37 \mathrm{~B}$ \\
\hline Rice straw & $10.42 b$ & $9.07 \mathrm{~d}$ & $9.74 \mathrm{~B}$ & $2210 \mathrm{e}$ & $2080 \mathrm{~g}$ & $2145 \mathrm{C}$ & $85.10 \mathrm{~d}$ & $79.33 \mathrm{e}$ & $82.22 \mathrm{C}$ & $15.49 \mathrm{bc}$ & $12.32 \mathrm{ac}$ & 13.91B \\
\hline White plastic & $10.47 \mathrm{~b}$ & $8.91 \mathrm{de}$ & $9.69 \mathrm{~B}$ & $2367 \mathrm{c}$ & $2341 \mathrm{~d}$ & $2354 \mathrm{~B}$ & $96.89 \mathrm{~b}$ & $94.80 \mathrm{c}$ & $95.85 \mathrm{~B}$ & $15.93 \mathrm{ab}$ & $12.32 \mathrm{ab}$ & $14.12 \mathrm{~A}$ \\
\hline Black plastic & $12.10 \mathrm{a}$ & $10.54 b$ & $11.32 \mathrm{~A}$ & $2467 \mathrm{a}$ & $2419 b$ & $2443 \mathrm{~A}$ & $102.10 \mathrm{a}$ & $97.70 \mathrm{~b}$ & $99.90 \mathrm{~A}$ & $15.94 \mathrm{a}$ & $12.25 \mathrm{a}$ & $14.10 \mathrm{~A}$ \\
\hline Mean & $10.70 \mathrm{~A}$ & $9.24 \mathrm{~B}$ & & $2287 \mathrm{~A}$ & $2208 \mathrm{~B}$ & & $90.48 \mathrm{~A}$ & $86.10 \mathrm{~B}$ & & $15.46 \mathrm{~A}$ & $12.29 \mathrm{~A}$ & \\
\hline
\end{tabular}

Means followed with the same letter (s) within each column or row are not significantly different according to Duncan's Multiple Range test at $5 \%$ level. $I_{1}$ : irrigation when $25 \%$ of available soil moisture was depleted. $\quad I_{2}$ : Irrigation when $50 \%$ of available soil moisture was depleted. 
3. Fruit quality.

- Fruit physical properties:

Concerning the effect of the investigated mulching treatments on both fruit physical characters i.e. fruit weight and fruit firmness, data in Table (8) revealed clearly that both the fruit weight and fruit firmness responded significantly to mulching treatments as compared to the control. Hence the heaviest fruit weight and firmness fruit texture of apricot fruits were statistically in closed relationship to Canino apricot trees mulched by black plastic treatment followed significantly by both (white and rice straw) treatments respectively. Meanwhile, control treatment was statistically the inferior, whereas, it resulted in the lightest fruit weight and softened fruits in both seasons of study. Furthermore, as for the response of both fruit weight and firmness to the two irrigation regime levels $\left(\mathrm{I}_{1}\right.$ and $\left.\mathrm{I}_{2}\right)$, data in the same Table pointed out that, an obvious significantly increase in fruit weight and statistically decrease in fruit flesh firmness were generally exhibited by those treated tree with the first irrigation regime level $\left(\mathrm{I}_{1}, 25 \%\right)$. Such trend was true during both 2016 and 2017 seasons of study. Moreover, data tabulated in same Table displayed obviously that, both combination treatment of the (black plastic $\mathrm{x}_{1}$ ) and (black plastic $\mathrm{x} \mathrm{I}_{2}$ ) were induced fruits had significantly the highest values of F WT and the firmest flesh texture during the first and second seasons, respectively. However, the control treatment was statistically the inferior as produced fruits had the least values of fruit and the most softened fruits in the two seasons of study. On the other hand, the other combinations were treatments were intermediate as compared to the above-mentioned two extremes. This trend was detected in both seasons of study.

Table 8. Effect of water irrigation regime, mulching treatments and their interaction on fruit Weight (g) and fruit firmness of apricot trees during 2016 and 2017 seasons.

\begin{tabular}{lcccccc}
\hline Irrigation & \multicolumn{3}{c}{ Fruit Weight (g) } & \multicolumn{2}{c}{ Fruit firmness (Ib/inch2) } \\
\cline { 2 - 7 } Mulching & $\mathbf{I}_{\mathbf{1}}$ & \multicolumn{1}{c}{$\mathbf{I}_{\mathbf{2}}$} & Mean & $\mathbf{I}_{\mathbf{1}}$ & $\mathbf{I}_{\mathbf{2}}$ & Mean \\
\hline & & & Season; 2016 & & & \\
Control & $33.89 \mathrm{f}$ & $35.21 \mathrm{e}$ & $34.55 \mathrm{C}$ & $9.56 \mathrm{~g}$ & $10.00 \mathrm{f}$ & $9.78 \mathrm{D}$ \\
Rice straw & $37.83 \mathrm{~d}$ & $38.38 \mathrm{bc}$ & $38.11 \mathrm{~B}$ & $10.29 \mathrm{e}$ & $10.54 \mathrm{~d}$ & $10.42 \mathrm{C}$ \\
White plastic & $38.77 \mathrm{~b}$ & $38.00 \mathrm{~cd}$ & $38.39 \mathrm{~B}$ & $11.34 \mathrm{~b}$ & $11.05 \mathrm{c}$ & $11.20 \mathrm{~B}$ \\
Black plastic & $40.55 \mathrm{a}$ & $40.70 \mathrm{a}$ & $40.62 \mathrm{~A}$ & $12.27 \mathrm{a}$ & $12.32 \mathrm{a}$ & $12.29 \mathrm{~A}$ \\
Mean & $37.76 \mathrm{~B}$ & $38.07 \mathrm{~A}$ & & $10.86 \mathrm{~B}$ & $10.98 \mathrm{~A}$ & \\
\hline & & & & & & \\
Control & $36.45 \mathrm{f}$ & $37.01 \mathrm{e}$ & $36.73 \mathrm{C}$ & $9.84 \mathrm{~g}$ & $10.17 \mathrm{f}$ & $10.00 \mathrm{D}$ \\
Rice straw & $38.20 \mathrm{~d}$ & $38.50 \mathrm{~d}$ & $38.35 \mathrm{~B}$ & $10.76 \mathrm{e}$ & $10.90 \mathrm{e}$ & $10.83 \mathrm{C}$ \\
White plastic & $40.54 \mathrm{c}$ & $40.95 \mathrm{~b}$ & $40.75 \mathrm{~A}$ & $11.64 \mathrm{c}$ & $11.37 \mathrm{~d}$ & $11.51 \mathrm{~B}$ \\
Black plastic & $40.40 \mathrm{c}$ & $41.40 \mathrm{a}$ & $40.90 \mathrm{~A}$ & $11.92 \mathrm{~b}$ & $12.23 \mathrm{a}$ & $12.08 \mathrm{~A}$ \\
Mean & $38.90 \mathrm{~B}$ & $39.47 \mathrm{~A}$ & & $11.04 \mathrm{~B}$ & $11.17 \mathrm{~A}$ & \\
\hline
\end{tabular}

Means followed with the same letter (s) within each column or row are not significantly different according to Duncan's Multiple Range test at $5 \%$ level.

$I_{1}$ : irrigation when $25 \%$ of available soil moisture was depleted.

$I_{2}$ : Irrigation when $50 \%$ of available soil moisture was depleted .

- Fruit chemical characteristics:

Referring the response of some fruit chemical properties (TSS \%, acidity, TSS/acid ratio and total sugars) to the effect different mulching treatments under study. Data in Table (9) showed clearly that both TSS\% and TSS/acid ratio as well as total sugar were statistically in closed relationship to those apricot trees mulching with black plastic. However, treated trees with black plastic treatment induced significantly the highest values of TSS \%, TSS/acid ratio and total sugar followed statistically by both plastic and rice straw treatments, respectively. On the other hand, the control treatment was statistically the inferior as exhibited the lowest values of three studied fruit properties. Such trends were detected during both seasons of study. Contrary to that, the opposite trend was observed with fruit Juice acidity \% whereas, both control and rice straw treatments were induced significantly the highest values of acidity \%. Meanwhile, both black plastic and white plastic treatments resulted in the lowest significant values of acidity \% during 2016 and 2017 seasons of study, respectively. As for the effect of irrigation regimes treatments, data in the same Table indicated that, providing apricot trees with the $\mathrm{I}_{1}(25 \%)$ exhibited fruits had significantly the highest values of TSS \%. TSS/acidity ratio and total sugars as compared to the other treatment $\left(\mathrm{I}_{2}\right)$. On the other hand, changes in fruit juice acidity $\%$ to the effect of irrigation regimes levels treatments were so slight to reach significant and it could be safely neglected in the two seasons of study. With regard to the response of fruit chemical properties of apricot trees to the interaction effect, data in Table (9) indicated that, the effect of each investigated factor (mulching and irrigation regimes) reflected obviously on its own combination and various were significantly quite evident. Anyhow, (mulching with black plastic x $I_{1}$ irrigation regimes) combination treatment exhibited statistically the highest values of TSS \%, TSS/acidity $\%$ and total sugar in the two seasons of study. These results were in the same line with Abd El-Messeih and El-Gendy (2004a) on apricot. From data in both studied seasons it was obvious that, fruits produced from trees grown under dry conditions were significantly higher in the values of juice acidity. The lowest value was obtained from irrigation level $\left(\mathrm{I}_{1}\right)$.

\section{Leaf mineral contents:}

Data in Table (10) showed obviously that, leaf macro element contents i.e.(N, P \& K) were 
significantly increased by using mulching treatments in this study as compared to the control in the two seasons except with leaf $\mathrm{P}$. content which showed insignificantly effect by all used mulching treatments in the first season only. However, the richest leaves in their N, K \& P content were exhibited significantly by mulching trees with black plastic in the two seasons of study. Meanwhile the opposite trend was detected with control (untreated trees) treatment which had statistically the poorest leaves in their macro-elements contents (N, P \& K) where studied during both 2016 \& 2017 seasons of study. Concerning the leave content of (N, P \& K) of apricot trees under the two levels of irrigation regimes $\left(I_{1} \& I_{2}\right)$ data indicated that, the first level $\left(I_{1}\right)$ was superior as exhibited the richest leaves and the highest values for both $\mathrm{N} \& \mathrm{~K}$ contents during both seasons of study. Whereas with leaf $\mathrm{P}$ content the differences between two levels irrigation regime $\left(\mathrm{I}_{1} \& \mathrm{I}_{2}\right)$ were so little to reach level of significance. It could be noticed the absent of significance in the response of $\mathrm{P}$ leave content to both levels of irrigation regimes was detected in the two season of study.

These findings were supported by those obtained by Neilsen et al. (1986) and Thakur et al. (1997) on apple trees and Zeerban (2004) on grapevines they mentioned that, soil mulching treatment increased leaf mineral content under polyethylene mulching. These results may be attributed to the mulching effect on improving root growth and respiration rate due to modifying soil temperature and moisture content, which in turn, created a suitable condition for soil microorganisms. These modification in soil condition may be responsible for increasing nutrients absorption via roots.

Table 9. Effect of water irrigation regime, mulching treatments and their interaction on some fruit chemical properties of apricot trees during 2016 and 2017 seasons

\begin{tabular}{|c|c|c|c|c|c|c|c|c|c|c|c|c|}
\hline \multirow{2}{*}{$\begin{array}{l}\text { Irrigation } \\
\text { Mulching } \\
\end{array}$} & \multicolumn{3}{|c|}{ TSS \% } & \multicolumn{3}{|c|}{ Acidity \% } & \multicolumn{3}{|c|}{ TSS/acid ratio } & \multicolumn{3}{|c|}{ Total sugars } \\
\hline & I1 & I2 & Mean & I1 & I2 & Mean & I1 & I2 & Mean & I1 & I2 & Mean \\
\hline & \multicolumn{12}{|c|}{ Season; 2016} \\
\hline Control & $10.6 \mathrm{~d}$ & $10.0 \mathrm{e}$ & $10 \mathrm{C}$ & $0.4 \mathrm{a}$ & $0.422 \mathrm{a}-\mathrm{c}$ & $0.427 \mathrm{~A}$ & $25.1 \mathrm{e}$ & $23.2 \mathrm{f}$ & $24.2 \mathrm{C}$ & $26.7 d$ & $25.3 \mathrm{e}$ & $26.0 \mathrm{C}$ \\
\hline Rice straw & $10.6 \mathrm{~d}$ & $10.4 \mathrm{de}$ & $10.5 \mathrm{C}$ & $0.426 a b$ & $0.421 \mathrm{a}-\mathrm{c}$ & $0.424 \mathrm{~A}$ & $25.1 \mathrm{e}$ & $24.4 \mathrm{e}$ & $24.8 \mathrm{C}$ & $28.4 b$ & $26.7 d$ & $27.5 \mathrm{~B}$ \\
\hline White plastic & $11.7 \mathrm{c}$ & $11.4 \mathrm{c}$ & $11.5 \mathrm{~B}$ & $0.403 b-d$ & $0.399 \mathrm{~cd}$ & $0.401 \mathrm{~B}$ & $29.3 \mathrm{c}$ & $28.3 d$ & $28.8 \mathrm{~B}$ & $28.6 b$ & $27.4 \mathrm{c}$ & $28.0 \mathrm{~B}$ \\
\hline Black plastic & $12.7 \mathrm{a}$ & $12.2 \mathrm{~b}$ & $12.5 \mathrm{~A}$ & $0.386 \mathrm{~d}$ & $0.377 \mathrm{~d}$ & $0.382 \mathrm{C}$ & $33.8 \mathrm{a}$ & $31.7 \mathrm{~b}$ & $32.7 \mathrm{~A}$ & $30.1 \mathrm{a}$ & $29.0 \mathrm{~b}$ & $29.6 \mathrm{~A}$ \\
\hline \multirow[t]{2}{*}{ Mean } & $11.4 \mathrm{~A}$ & $11.0 \mathrm{~B}$ & & $0.411 \mathrm{~A}$ & $0.405 \mathrm{~A}$ & & $28.3 \mathrm{~A}$ & $26.9 \mathrm{~B}$ & & $28.4 \mathrm{~A}$ & $27.1 \mathrm{~B}$ & \\
\hline & \multicolumn{12}{|c|}{ Season; 2017} \\
\hline Cont & $10.9 \mathrm{de}$ & $10.6 \mathrm{e}$ & $10.7 \mathrm{C}$ & $0.424 a$ & $0.420 \mathrm{a}$ & $0.422 \mathrm{~A}$ & $25.9 \mathrm{wf}$ & $24.9 f$ & $25.4 \mathrm{C}$ & $26.5 d$ & $26.1 d$ & $26.3 \mathrm{C}$ \\
\hline Rice straw & $11.1 \mathrm{~cd}$ & $10.5 \mathrm{e}$ & $10.8 \mathrm{C}$ & $0.413 a$ & $0.413 \mathrm{a}$ & $0.413 \mathrm{~A}$ & $26.8 \mathrm{e}$ & $25.4 \mathrm{f}$ & $26.1 \mathrm{C}$ & $28.0 \mathrm{bc}$ & $27.6 \mathrm{c}$ & $27.8 \mathrm{~B}$ \\
\hline White plastic & $12.1 \mathrm{~b}$ & $11.4 \mathrm{c}$ & $11.8 \mathrm{~B}$ & $0.406 \mathrm{ab}$ & $0.394 b c$ & $0.400 \mathrm{~B}$ & $30.8 \mathrm{c}$ & $28.1 d$ & $29.4 \mathrm{~B}$ & $28.3 b$ & $28.0 \mathrm{bc}$ & $28.2 \mathrm{~B}$ \\
\hline Black plastic & $12.8 \mathrm{a}$ & $12.3 b$ & $12.6 \mathrm{~A}$ & $0.378 \mathrm{~cd}$ & $0.364 d$ & $0.371 \mathrm{C}$ & $35.3 \mathrm{a}$ & $32.6 b$ & $34.0 \mathrm{~A}$ & $29.7 \mathrm{a}$ & $29.4 \mathrm{a}$ & $29.6 \mathrm{~A}$ \\
\hline Mean & $11.7 \mathrm{~A}$ & 11.2B & & $0.405 \mathrm{~A}$ & $0.398 \mathrm{~A}$ & & $29.7 \mathrm{~A}$ & $27.8 \mathrm{~B}$ & & $28.1 \mathrm{~A}$ & $27.8 \mathrm{~B}$ & \\
\hline
\end{tabular}

Means followed with the same letter (s) within each column or row are not significantly different according to Duncan's Multiple Range test at $5 \%$ level. $I_{1}$ : irrigation when $25 \%$ of available soil moisture was depleted. $\quad I_{2}$ : Irrigation when $50 \%$ of available soil moisture was depleted .

Table 10. Effect of water irrigation regime and mulching treatments on some leaf macronutrients (N, P and $K$ ) contents of apricot trees in 2016 and 2017 seasons.

\begin{tabular}{|c|c|c|c|c|c|c|c|c|c|}
\hline \multirow{2}{*}{$\begin{array}{l}\text { Irrigation } \\
\text { Mulching }\end{array}$} & \multicolumn{3}{|c|}{$\mathbf{N}(\%)$} & \multicolumn{3}{|c|}{$\mathbf{P ( \% )}$} & \multicolumn{3}{|c|}{ K (\%) } \\
\hline & $\mathbf{I}_{1}$ & $\mathbf{I}_{2}$ & Mean & $\mathbf{I}_{1}$ & $\mathbf{I}_{2}$ & Mean & $\mathbf{I}_{1}$ & $\mathbf{I}_{2}$ & Mean \\
\hline & \multicolumn{9}{|c|}{ Season; 2016} \\
\hline Control & $2.02 \mathrm{~b}$ & $2.07 \mathrm{~b}$ & $2.04 \mathrm{BC}$ & $0.296 \mathrm{a}$ & $0.306 \mathrm{a}$ & $0.301 \mathrm{~A}$ & $2.14 \mathrm{de}$ & $2.03 \mathrm{e}$ & $2.09 \mathrm{D}$ \\
\hline Rice straw & $2.23 \mathrm{ab}$ & $2.09 \mathrm{~b}$ & $2.16 \mathrm{~B}$ & $0.309 \mathrm{a}$ & $0.320 \mathrm{a}$ & $0.315 \mathrm{~A}$ & $2.31 d$ & $2.21 \mathrm{de}$ & $2.26 \mathrm{C}$ \\
\hline White plastic & $2.55 \mathrm{a}$ & $2.25 \mathrm{ab}$ & $2.40 \mathrm{~A}$ & $0.323 \mathrm{a}$ & $0.299 \mathrm{a}$ & $0.311 \mathrm{~A}$ & $2.94 b$ & $2.64 \mathrm{c}$ & $2.79 \mathrm{~B}$ \\
\hline Black plastic & $2.48 \mathrm{a}$ & $2.37 \mathrm{ab}$ & $2.43 \mathrm{~A}$ & $0.314 \mathrm{a}$ & $0.324 \mathrm{a}$ & $0.319 \mathrm{~A}$ & $3.19 \mathrm{a}$ & $3.11 \mathrm{ab}$ & $3.15 \mathrm{~A}$ \\
\hline \multirow[t]{2}{*}{ Mean } & $2.64 \mathrm{~A}$ & $2.39 \mathrm{~B}$ & & $0.311 \mathrm{~A}$ & $0.312 \mathrm{~A}$ & & $2.64 \mathrm{~A}$ & $2.50 \mathrm{~B}$ & \\
\hline & \multicolumn{9}{|c|}{ Season; 2017} \\
\hline Control & $2.19 \mathrm{~cd}$ & $2.23 \mathrm{~cd}$ & $2.21 \mathrm{BC}$ & $0.274 d$ & $0.278 \mathrm{~d}$ & $0.276 \mathrm{C}$ & $2.49 \mathrm{c}$ & $2.15 \mathrm{~d}$ & $2.32 \mathrm{C}$ \\
\hline Rice straw & $2.36 \mathrm{a}-\mathrm{c}$ & $2.24 d$ & $2.30 \mathrm{AB}$ & $0.314 b c$ & $0.303 \mathrm{~cd}$ & $0.308 \mathrm{~B}$ & $2.82 \mathrm{~b}$ & $2.52 \mathrm{c}$ & $2.67 \mathrm{~B}$ \\
\hline White plastic & $2.57 \mathrm{ab}$ & $2.42 \mathrm{~b}-\mathrm{d}$ & $2.50 \mathrm{~A}$ & $0.305 \mathrm{~cd}$ & $0.319 b c$ & $0.312 \mathrm{~B}$ & $2.81 b$ & $2.37 \mathrm{c}$ & $2.59 \mathrm{~B}$ \\
\hline Black plastic & $2.83 \mathrm{a}$ & $2.70 \mathrm{~cd}$ & $2.77 \mathrm{~A}$ & $0.354 \mathrm{a}$ & $0.343 \mathrm{ab}$ & $0.349 \mathrm{~A}$ & $3.22 \mathrm{a}$ & $3.10 \mathrm{a}$ & $3.16 \mathrm{~A}$ \\
\hline Mean & $2.49 \mathrm{~A}$ & $2.40 \mathrm{~B}$ & & $0.312 \mathrm{~A}$ & $0.311 \mathrm{~A}$ & & $2.84 \mathrm{~A}$ & $2.54 \mathrm{~B}$ & \\
\hline
\end{tabular}

Means followed with the same letter (s) within each column or row are not significantly different according to Duncan's Multiple Range test at $5 \%$ level. $I_{1}$ : irrigation when $25 \%$ of available soil moisture was depleted. $I_{2}$ : Irrigation when $50 \%$ of available soil moisture was depleted .

\section{Economic study:}

The economical comparative study between different treatments shown in Table (11) where calculated at the average of the two studied years. Total cost of production, incomes profits (L.E./fed) and net return (LE/fed.) of apricot trees as affected by available soil moisture depletion and mulching treatments.
Black polyethylene approximately with two seasons of mulching treatment was superior in total income ( $\mathrm{LE} / \mathrm{fed})$ which in turn increased the net return (LE/fed) (60245 \& 48720 LE), respectively comparing with other treatments. 
Table 11. Economic analysis as affected by available soil moisture depletion treatment and mulching treatments (average yield and applied water of 2 years).

\begin{tabular}{|c|c|c|c|c|c|c|c|c|c|c|}
\hline \multirow{2}{*}{\multicolumn{2}{|c|}{$\begin{array}{l}\text { Irrigation } \\
\text { Mulching } \\
\end{array}$}} & \multicolumn{5}{|c|}{ Cost of production } & \multicolumn{3}{|c|}{ Incomes Profits (L.E. /fed.) } & \multirow{2}{*}{$\begin{array}{c}\text { Net } \\
\text { return } \\
\text { (LE/fed) }\end{array}$} \\
\hline & & $\begin{array}{c}\text { Field } \\
\text { practices }\end{array}$ & $\begin{array}{l}\text { Hand } \\
\text { hoeing }\end{array}$ & Mulching & $\begin{array}{l}\text { Water cost } \\
\text { Irr. (LE) }\end{array}$ & $\begin{array}{c}\text { Total } \\
\text { (LE/fed) }\end{array}$ & $\begin{array}{c}\text { Fruit } \\
\text { LE/Kg }\end{array}$ & $\begin{array}{l}\mathrm{Kg} \\
\text { /fed }\end{array}$ & $\begin{array}{c}\text { Total } \\
\text { (LE/fed) }\end{array}$ & \\
\hline \multirow{4}{*}{$\mathrm{I}_{1}$} & Un-mulched & \multirow{4}{*}{9500} & 1700 & 0 & 2340 & 13450 & 5 & 13810 & 69050 & 55510 \\
\hline & Rice straw & & 1200 & 1100 & 1800 & 13600 & 5 & 14405 & 72025 & 58425 \\
\hline & White plastic & & 1400 & 1150 & 1710 & 13760 & 5 & 14705 & 73525 & 59765 \\
\hline & Black plastic & & 1400 & 1150 & 1680 & 13730 & 5 & 14795 & 73975 & 60245 \\
\hline \multirow{4}{*}{$\mathrm{I}_{2}$} & Un-mulched & \multirow{4}{*}{9500} & 1700 & 0 & 1980 & 13380 & 5 & 11875 & 59375 & 45995 \\
\hline & Rice straw & & 1200 & 1100 & 1680 & 13480 & 5 & 12145 & 60725 & 47245 \\
\hline & White plastic & & 1400 & 1150 & 1460 & 13510 & 5 & 12320 & 61600 & 48090 \\
\hline & Black plastic & & 1400 & 1150 & 1380 & 13430 & 5 & 12430 & 62150 & 48720 \\
\hline
\end{tabular}

\section{REFERENCES}

A.O.A.C. (2000). "Official Methods of Analysis (17 ${ }^{\text {th }}$ ed.). Association of Official Analytical Chemists" Washington, D.C.

Abd El-Messeih, W.M. and El-Gendy, R.W. (2004a) Effect of different trickle irrigation levels based on soil matric potential on; 1- Vegetative growth and yield of "Canino" apricot trees planted in sandy soils. Alex. Sci. Exch., 25 (3), 465-480.

Allen, R.G., Pereira, L.S., Raes, D. and Smith, M. (1998) Crop evapotranspiration irrigation and Drainage Paper No. 56, FAO, Rome, Italy.

Cottenie, A., Verlo, M., Kiekeus, L. Velghe, G. and Camerlynck, R. (1982). Chemical Analysis of plants and soils. Laboratory of Analytical and Agrochemistry State University, Ghent-Belgium

Devitt, D.A. Marris R.L. and Neuman D.S. (1994). Evapotranspiration and growth response of three woody ornamental species placed under varying irrigation regimes. J. Amer. Soc. Hort. Sci., 119 (3): 452-457.

Donk-van, S.J., Tollner, E.W., Steiner, J.L. and Evett, S.R. (2004). Soil temperature under a dormant Bermudagrass mulch: Simulation and measurement. American Society of Agricultural Engineers, 47(1): 91-98.

Doorenbos, J. and Pruitt, W.O. (1977) Guidelines for predicting crop water requirements. FAO Irrigation and Drainage Paper No. 24, (revised) FAO, Rome, Italy.

Douglas, C. and Sanders, G., 2001. Using Plastic Mulches and Drip Irrigation for Vegetable Gardens Published by the North Carolina Cooperative Extension Service. Reviewed 1/01 HIL-8033

El-Henawy, A.S. (2006). Effect of drip irrigation and soil mulching on some soil properties, yield and quality of "Navel" orange trees at North Delta. Ph.D. Thesis, Fac . Agric., Kafr El-Sheikh, Tanta Univ., Egypt.

Gimenez C.; Otto, R.F. and Castilla, N. (2002). Productivity of leaf and root vegetable crops under direct cover. Scientia Hort., 94: 1-11.

Hostetler, G., Merwin, I.A., Brown, M.G. and PadillaZakour, O. (2007) Influence of under vine floor management on weed competition, vine nutrition and yields of Pinot noir. Amer. J. Enol. Viticult., 58: $421-430$
Ibrahim, M.A (1981). Evaluation of different methods for calculating potential evapotranspiration in north Delta region. Ph .D. thesis, Fac. Agri. Alex. Univ.

Israelson, O.W. and Hansen. V.E. (1962). Irrigation principles and practices, 3rd ed., John Willey and Sons Inc., New York, USA

Jackson, M. L. and Ulrich, A. (1959). Analytical methods for use in plant analysis. Coll. of Agric. Exp. State Bull.766: 35 pp.

Jensen, M.E. (1968) Water consumption by Agriculture lands, In. Water deficit and plant growth, T.T. Kozlowski (Ed.), Academa press, New York. Vol. II. 1-22.

Jones, J.W.; Allen, L.H.; Shin, S.F.; Rogers, J.S.; Hammond, L.S.; Smajstrala, A. G. and Martsolf, J.D. (1984). Estimated and measured evapotranspiration for Florida climate, crops and soils. Rep. 840. University of Florida, Gainesville.

Khalifa, M.R. (1994). Effect of different types of mulching on water consumptive use of " Valencia" orange trees. J. Agric. Res., Tanta Univ., 20 (3): 591- 602

Khurshid, K.; Iqbal, M.; Arif, M.S. and Nawaz, A. (2006). Effect of tillage and mulch on soil physical properties and growth of maize. Int. J. Agric. Biol., 5: 593-6.

Kiristina, B., D., Todaugine, R. Pupaliene and Sinkeviciene, A. (2013). Effect of organic mulches on the content of organic carbon in the soil. Estonian J. Ecology, 62 (2): 100-106.

Klute, A. (1986). Methods of Soil Analysis. Part 1. 2nd ed. ASA and SSSA. Madison, Wisconsin, USA.

Levitt, D.G.; Simpson, J.R. and Tipton, J. L. (1995). Water use of two landscapes tree species in Tucson. J. Amer. Soc. Hort. Sci., 120: 409-416.

Liu, Yi, Wang, Jing, Liu, Dongbi, Li, Zhiquo, Zhang, Guoshi, Zhang, Tao, Yong, Xie, Juan, Pan, Junfeng and Chen, Fang (2014). Straw mulching reduces the harmful effects of extreme hydrological and temperature conditions in Citrus Orchards. Plos one. 9 (1), e87094:1-9.

Magness, J. R. and Taylor G. F. (1980). An improved type of pressure tester for the determination of fruit maturity. U.S. Dept. Agric. Circ., 350 8p.

Malik, C.P. and Singh, M.B. (1980). Plant enzemology. A text manual Kalayand, publish; New Delhi, 
Mikhael, G. B. (2007). Effect of some drip irrigation and mulching treatments on 1- Vegetative growth and nutritional status of "Anna" apple trees growing on new reclaimed soils. Minufiya, Jour. Agric. Res., 32 (4): 1155-1174.

Murphy, J. and Riely, J. P. (1962). A modified single method for the determination of phosphorus in natural water. Anal. Chemi. Acta, 27:31-36.

Mustafa, O.S.; Arshad, M.; Sattar, I. and Ali, S. (2003). Adoption of kostiak of model to determine the soil infiltration for surface irrigation methods under local conditions. Int. J. Agric. Biol., 1: 40-2

Neilsen, G.h.; Hogue, E.J. and Drought, B.G. (1986). Orchard soil management on soil temperature and apple trees. Canadian J. Soil Sci. 66:701-711.

Saif, U.; Matsudo, M.; Faros, M.; Hussain, S. and Habib, A. (2003). Effect of planting patterns and different irrigation levels on yield and yield component of maize (Zea mays L.). Int. J. Agric. Biol., 1: 64-69.

Sajjapongese, A., Ota, Y., Roam, Y.C., and Wu, C.L., (1989). Som aspects of cultural management in tomatoes at AVRDC. Asian Vegetable Research and Development Center, Shanhua, Tainan, Taiwan. pp. 349-357.

Sharma A.R., Singh R., Dhyani S.K., Dube R.K. (2010). Moisture conservation and nitrogen recycling through legume mulching in rainfed maize (Zea mays)-wheat (Triticum aestivum) cropping system. Nutrient Cycling in Agroecosystems, 87: 187-197

Shaw, R.H. (1959). Water use from plastic covered and uncovered corn plots. Agron. J., 51: 172-173

Sinkeviciene, A., Jodaugiene, D., Pupaliene, R. and Urboniene, M. (2009). The influence of organic mulches on soil properties and crop yield. Agron. Res., 7 (1): 485-491.

Smith, N. (1991). CROPWAT model for ETo calculation using Penman-Monteith method., Irrigation and Drainage Paper no. 46, FAO, Rome, Italy.
Snedecor, G. W. and Cochran,G. W. (1990). Statistical Methods. $8^{\text {th }}$ Ed The Iowa State Univ., press Ames, Iowa. U.S.A. pp.503-507.

Stackman, W.P. (1966). Determination of pore size by the air bubbling pressure method proceeding unesce Symp on water in the unsaturated zone 366- 372.

Thakur, G.C.; Chadha, T.R.; Verma, H.S. and Kumar, J. (1997). Effect of ciean cultivation, mulching and sod culture on mineral nutrition and root growth of apple cv. Red Dellcious . Indian J.Hort. 54 (10) :5357

Vavrina, C.S. and Roka, F.M. (2000). Comparison of plastic mulch and bare ground production and economics for short-day onion in a semitropical environment. Horticultural Technol., 10: 326-330.

Vites, F.G., (1965). Increasing water use efficiency by soil management. Amer. Soc. Agron., Madison,

Vogel, A. (1968). A Text Book of Quantitative Inorganic Analysis. Longmans, New York, pp. 1216.

Waller, R.A. and Duncan, C.B. (1969). A bays rule for symmetric multiple comparison problem Amer.State Assoc. Jour.1485-1503.

Weagand, G. L. (1962). Drying pattern of a sandyclay loam in relation to optimal depth of seeding. Agron. J. 54: 473-476.

William, J. and Lamont J.R., (1991). The use of plastic mulches for vegetable production. Department of Horticulture, Kansas State University Manhattan, ks 66506, USA.

Zeerban, S.M. (2004) Vegetative growth, yield and fruit quality of Thompson seedless grapevines as affected by some soil mulching materials. J. Agric. Sci. Mansoura univ., 29(6) :3515-352 9.

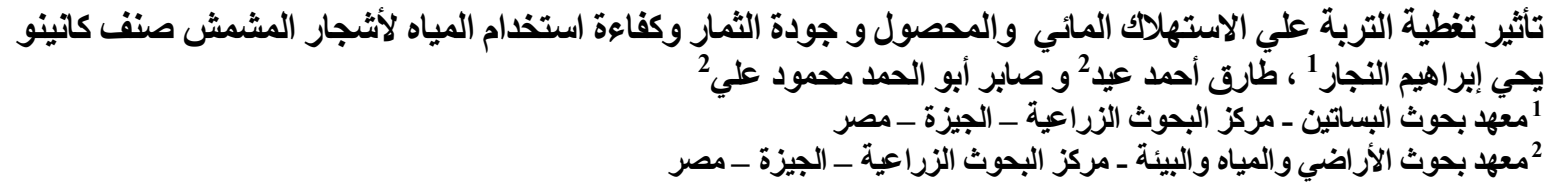

أجريت الدراسة بالمزر عة البحثية بمحطة بحوث البساتين بالقناطر الخيرية خلال موسمي 2016، 2017 على أثجار المشمش (كانينو)

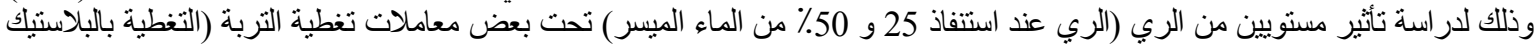

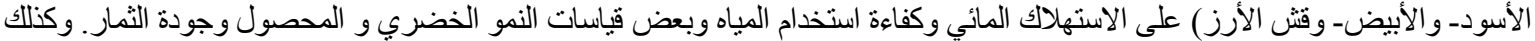

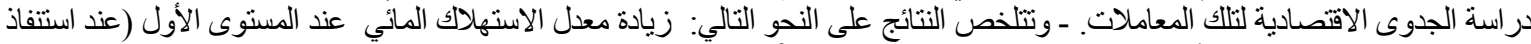

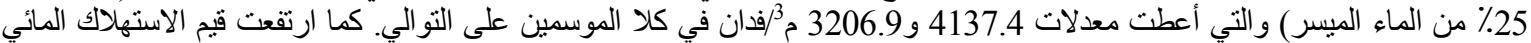

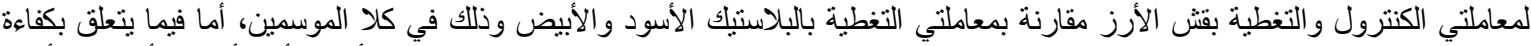

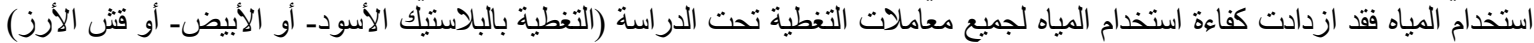

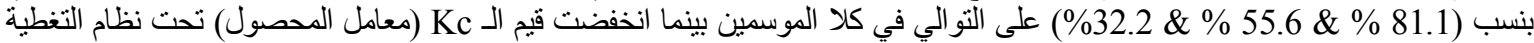

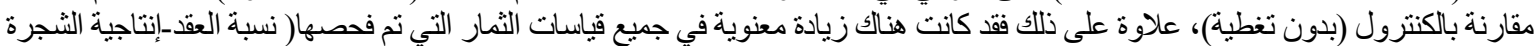

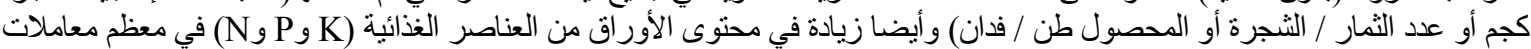

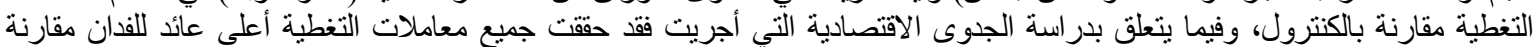

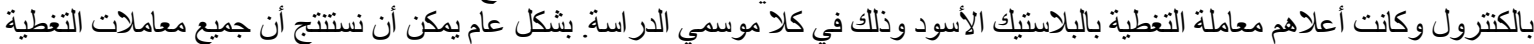
سواء بالبلاستيك الأبيض أو الأسود أو قش الأرز كانت ألكثر المعاملات فعالية. 